\title{
Incompletely Digitized ECG Leads
}

National Cancer Institute

\section{Source}

National Cancer Institute. Incompletely Digitized ECG Leads. NCI Thesaurus. Code

C114169.

A digital electrocardiographic recording which was digitized from paper ECG tracings and which does not contain all leads present on the original paper printout. (CDISC) 